\title{
STAKEHOLDER ANALYSIS: DEVELOPMENT AND EMPOWERMENT STUDENT REGIMENT IN INDONESIA DEFENSE SYSTEM
}

\author{
Faisal Ahmadani ${ }^{* 1}$ 《 iD , Adis Imam Munandar ${ }^{2}$, Agape Zacharia R.D ${ }^{3}$ iD \\ ${ }^{* 1}$ School of Strategic and Global Studies, University of Indonesia, Indonesia \\ 2 School of Strategic and Global Studies, University of Indonesia, Indonesia \\ ${ }^{3}$ Defense Strategy Faculty, Indonesia Defense University, Indonesia
}

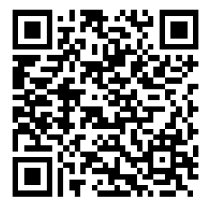

DOI: https://doi.org/10.29121/granthaalayah.v8.i12.2020.2664

Article Type: Research Article

Article Citation: Faisal Ahmadani, Adis Imam Munandar, and Agape Zacharia R.D. (2020).

STAKEHOLDER ANALYSIS:

DEVELOPMENT AND

EMPOWERMENT STUDENT

REGIMENT IN INDONESIA DEFENSE

SYSTEM. International Journal of Research -GRANTHAALAYAH, 8(12), 54-59.

https://doi.org/10.29121/granthaa

layah.v8.i12.2020.2664

Received Date: 02 December 2020

Accepted Date: 25 December 2020

Keywords:

Student

Regiment

Stake

Holder

Defense

Policies

\section{ABSTRACT}

The history of Student Regiment in Indonesia is an integral part of Indonesia history as well. But after Indonesia democracy reform, militaristic identity of Student Regiment and degradation Student Regiment's role in Indonesia Defense System face dilemmatic discourse especially in development and empowerment. This paper applies qualitative method and stakeholder analysis with comparative approach. Based on Law Np. 23/2019, Student Regiment development and empowerment policies should be reviewed. All the policies and regulations on Student Regiment in the future could be supporting Indonesia Defense System management to gain deterrent as the final goal, and Four Ministers Joint Agreement Letter in 2014 should be replace with updated and strong regulation.

\section{INTRODUCTION}

As the efforts for defending the country, Indonesia executes the rights and also the compulsories all citizens to defend its country and citizen have an obligation to be actively involved in accordance with Indonesia's constitution. The Total Defense System's characteristics is executed through synergy, integrated, and coordinated military and non-military defense in order to tackle military, non-military and hybrid threats (Ministry of Defense, 2015, p57). Student Regiment (Resimen Mahasiswa) has a different role as a student activity unit in many universities or colleges in Indonesia. During Indonesia Independence War (1945-1949), student participation in war to defense Indonesia Freedom was starting. On June 3 1946, the president of Republic of Indonesia declared to rename Republic of Indonesia Armed Forces (Tentara Republik Indonesia), with a new name was Indonesia National Armed Forces (Tentara Nasional Indonesia). The rename also referred to reforming the armed forces, and one of the steps to reform

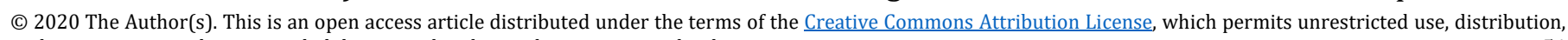
and reproduction in any medium, provided the original author and source are credited. 
was establishing the $17^{\text {th }}$ Brigade/Student Army. The Brigade was composing not only universities or college students but also high school students. After the war, based on Law No. 29/1954, the first universities and colleges military reserve component had been established, within Student Military Compulsory Training Program (Wajib Latih Mahasiswa) and the pilot project conducted in Bandung, on June 13 1959, and known as WALA 59 (Waris, et al., 2013, p5-6). Student Regiment's history is showing it's a long journey with two roles, both as reserve component and also as supporting component in Indonesia Defense System. The Indonesian struggle has provided valuable experience with the noble values, which are still maintained. This is possible through the national struggle in seizing and retaining the independence of Indonesia, which always involve citizen's participation. The participation of citizens in the state defense, or defined as Bela Negara (Ministry of Defense, 2015, p101). Supporting Component structuring involves all national defense resources, which include people, natural and artificial resources, and national facilities for national defense purposes. The component is organized through people's participation in the preparation of the national defense policy, state defense component, and the financial sustainability of the defense industry through state financial management (Ministry of Defense, 2015, p112).

Transformation of the Student Regiment's role in Indonesia Defense is impacting Student Regiment existence in many universities and colleges in Indonesia. Many of Student Regiment Unit in several universities and colleges in have been collapsed because of the change of many policies on Student Regiment development and empowerment. Recently Indonesia Defense System has no reserve component, and exactly, Student Regiment is a potential trained citizen institution to develop as reserve component, at least if comparing with others trained citizens such as: military or police veterans, non-government organization members or private security officers. Also, comparing with other countries in South East Asia, many students in both university and college take their role as reserve component in Reserve Officer Units. The Student's role as reserve officers give them not only for building citizens awareness but also to increase national defense capacity and capability.

\section{RESEARCH METHOD}

This study research method is qualitative method and use stakeholder analysis to analyze "what each stakeholder's stand for" which used to help executives think through the effects that their actions have on external groups at a macro level. Without such an analysis, answering "what do we stand for" will be done in a vacuum, and the result may well not be acceptable to those groups whom it will affect (Freeman, R. Edward, 1951, p95). This study also comparing other programs which similarly with Student Regiment in Indonesia, especially in South East Asia countries as strategic environment. Comparative approach focusses on two similar programs in neighbor countries: Malaysia and Philippine.

\section{RESULTS AND DISCUSSIONS}

\section{Student Regiment Policies}

Based on Law No. 3/2002 on National Defense, the role of Student Regiment has been changed from a part of reserve component to supporting component in Indonesia Defense System. The change also continued by a Joint Agreement Letter of four Ministers: Minister of Defense (No. KB/ 11/XII/2014, Minister of Domestic Affairs (No. 421.73/6660A/SJ), Minister of Research and High Education (No. 6/M/MOU/XII/2014) and Minister of Youth and Sport (No. 1175/2014) on Student Regiment Development and Empowerment in State Defense. Later, based on Law No. 23/2019 on National Resources Man agent for National Defense article 20's explanation, the role Student Regiment clearly explains as a part of Trained Citizen (Warga Terlatih) and has role to support both reserve and main component in Indonesia Defense System.

Law No. 23/2019 Article 22 explains that ministry which conducted government's affairs in defense in cooperation with others ministry/institution or local government are ordering or structuring supporting component which under management of ministry/institution or local government. Article 25 later clearly explains that developing of supporting component activities are: socialization, technical guidance and simulation. According to the law, Ministry of Defense has responsibility as the leading sector for ordering, structuring and also developing supporting components including Student Regiment and ties in cooperation with other government stakeholders. 
Indonesia defense strategy considers South East Asia countries as a strategic region. Considering ASEAN as strategic environmental is guiding the planning in defense program in Indonesia is strategic planning. The future strategic planning ties of Indonesia's defense with the pattern of planning formulation is influenced by issues and phenomena developing in Southeast Asia. Dynamics that occur between ASEAN countries in defense policy instruments focuses on strengthening national defense posture and structures (Nugraha, 2017, p217). That's why, student participation in defense program in ASEAN countries must be one of consideration in Student Regiment development and empowerment policies. After Law No. 23/2019 is issued, strategic defense planning must be reviewed, including all policies for strengthening national defense posture and structures, and Student Regiment's policies also must be reviewed, prior to to review Joint Agreement Letter between four Ministry in 2014 which agreed before Law No. 23/2019 is issued.

In Philippine, a similar program with Student Regiment in Indonesia, which was established within a National Service Training Program (NSTP), and one of the program is The Reserve Officers' Training Corps (ROTC) which is hereby made optional and voluntary upon the effectivity, The stakeholders which have authorities and responsibilities are : The Commission on Higher Education (CHED) and Technical Education and Skills Development Authority (TESDA), in consultation with the Department of National Defense (DND), Philippine Association of State Universities and Colleges (PASUC). Coordinating Council of Private Educational Associations of the Philippines (COCOPEA) and other concerned government agencies may design and implement such other program components as may be necessary (Crisostomo, 2017, p831). It's means, in Philippine the main stakeholders are The Commission on Higher Education (CHED) and Technical Education and Skills Development Authority (TESDA) and the Department of National Defense (DND) has a role to assistance the program. For other reasons, consultation also involving many stakeholders as may be necessary. This pattern in developing and empowering ROTC in Philippine shows a similar pattern with Student Regiment in Indonesia, but also shows a difference role of the program: in Philippine as reserve component and in Indonesia as supporting component, or other way to describe, Student Regiment has been degraded in Indonesia Defense System.

How about Malaysia? ROTU or Reserve Officer Training Unit, established in 1979, the brainchild of Brig Gen Dato 'Abul 'As bin Ismail, director of the Territorial Army. Its main goal is to train students with military knowledge, while contributing to national defense (Hisyam, 2016, p2). Defense team composed of university undergraduates is seen to be based on inspiration from the government for shaping the physical and mental well-being of citizens in the face of several forthcoming events, and also another consideration is second line of strength, the concept of defense of a nation seen as a young warrior who ready to volunteer. As far as military theory is concerned, national defense cannot be depending on troops alone, because the voluntary back is also essential, thus, Reserve Officer Training Unit (ROTU) is a cooperation program between the Ministry of Defense and the Ministry of Education (Khan, et al., 2019, p78). Student Regiment in Indonesia established before ROTU or Reserve Officer Training Unit established in Malaysia is established, but Indonesia dynamic in democracy or Indonesia reform (reformasi) brought the Student Regiment at a dilemmatic position, as civil defense unit in universities or colleges with military identity. The polemic about Student Regiment position was coloring the existence of them during the first years of Indonesia democracy reform. Student Regiment faced many resistances not only from internal campus but also from many human right activist and politic scholar who's claimed that Student Regiment is a way to militarize the campus. The role degradation of Student Regiment was restructuring them from second line of strength to third line of strength, but with similar goal to gain a goal: train military skill among student and an opportunity for them to contribute in National Defense. Other difference between ROTU in Malaysia with Student Regiment in Indonesia is historical background. Student Regiment historical background was student participation during Indonesia Independence War. The historical background later inspired Indonesia government to prepare all student as reserve component and under command of Indonesia Armed Forces (TNI). Military's intervention in ROTU also described that in Malaysia, military has a role for preparing reserve component, but the program is conducting between the Ministry of Defense and the Ministry of Education. Malaysia shows a simple pattern in how the program is running. Comparing in Indonesia or Philippine with more than two stakeholders. The simple way also shows that a simple pattern in defense component management.Following Malaysia's way could be better for Indonesia. A simple pattern in development and empowerment Student Regiment lead by Ministry of Defense and Mistry of Culture and Education. The Higher Education Directorate of Ministry of Culture and Education in cooperation with the Defense Potency Directorate of Ministry of Defense. But, if necessary, other stakeholders could be involved. As trained volunteers, Student Regiment members have capability to support civil defense activities for example in natural disaster relief activities, Search and Rescue (SAR) activities and et cetera. 
Faisal Ahmadani, Adis Imam Munandar, and Agape Zacharia R.D

The actor with the highest priority and become the most important criteria in the establishment of state defense reserve components in ASEAN countries generated research finding that training is a the most accommodating subpattern the interest of competence improvement to realize deterrence in the field of state defense.

\section{Stakeholder's Identification}

Based on laws and regulations, especially four parties Joint Agreement in 2014 there are four ministries which have interest on Student Regiment: Ministry of Defense, Ministry of Domestic Affairs, Ministry of Youth and Sport and Ministry of Culture and Education. As a unit of activity in campus, higher education institution (university or college) has an authority to manage and control Student Regiment unit in the campus. As an autonomous authority, university or college has an authority to manage their internal affairs without external intervene with limitation in line with education laws and regulations. On other hand, as the government institution for handling education affairs, Ministry of Culture and Education has authority to manage and control all higher education institutions based on education laws and and regulations, and two levels of stakeholder are identified: local stakeholder and national stakeholder, campus authority is local stakeholder and Ministry of Couture and Education is national stakeholder. The problem later come from Ministry of Defense, the Ministry has no lower-level institution that why military unit has an opportunity to involve in Student Regiment development and empowerment and contributing as coaching and training institution. For defense interest, Ministry of Defense is national stakeholder and military unit (overall Indonesia) is local stakeholder. Ministry of Culture and Education and Ministry of Defense are two of key stakeholders or the first line stakeholder, and other government institutions are secondary line stakeholder.

\section{Stakeholder's Interest and Policy Review}

The four parties' Joint Agreement Letter in 2014 is issued based on Law NO. 3/2002 on National Defense. The goal of the agreement is state defense awareness in higher education's development and empowerment, and Student Regiment as a student activity unit in higher education institution has a role as state defense student activity unit. After Law No. 23/2019, the role of Student Regiment is not only as state defense student activity unit, but as trained citizen unit in Indonesia Defense System and also a part of National Supporting Human Resources in Indonesia National Resources Management for National Defense. The historical background of the Total People's Defense and Security System contributes to the political ideology of the military and its relation with the existence of militia groups. Indonesia should consider re-interpretation by using the human rights approach to implementation based on a clear and precise definition the Total People's Defense and Security System (Bhatara Ibnu Reza, 2017, p174). Law No. 23/2019 Article 64 explains that supporting component (including human resources) will be increased as a part of reserve component with upgrading capability during mobilization. The past experiences of Student Regiment shown their contribution and participation as reservist and not militia, similar with recent ROTU in Malaysia or ROTC in Philippine. Indonesia Ministry of Defense should consider re-interpretation Student Regiment policies based on a clear and precise definition the Total People's Defense and National Resources Management according to Law No 23/2019.

The politics of curriculum today are also clearly applied by the new Minister of Education and Culture of the Republic of Indonesia, Nadiem A. Makarim. Through the Merdeka Belajar (Free to Learn) policy and the Kampus Merdeka (Free Campus) government policy in education is trying to bring the young generation of Indonesia to survive in the $21^{\text {st }}$ century (Dinn Wahyudin and Andi Suwirta, 2020, p153). Preparing the next generation to survive in the future will not realize without deterrent effect. Freedom to choose for student not only in curriculum perspective but also co-curriculum perspective. Student has an independence option to join with Student Regiment in the campus voluntary, and this value not only as state defense awareness but also a student's personal interest on military skills.

In order to improve the competency of Indonesian citizens who participate in defending state either as members of state defense reserve component or as state defense cadre, so as to have deterrence towards wide range of threats (Setiawan, 2018, pp25-26). Except reserve component program is a highest priority in Indonesia Defense System, in fact until now there is no a real program to realize it. Indonesia government has no a clear blue print for ordering or structuring reserve component and Student Regiment should be one option to realize the reserve component in Indonesia Defense System. Indonesia's deterrent effect will be the basic consideration for developing and empowering Student Regiment. Student Regiment deployment in many universities and colleges all around Indonesia will be considerable for strengthening Indonesia Defense capacity. A role of Student Regiment as state 
Stakeholder Analysis: Development and Empowerment Student Regiment in Indonesia Defense System

defense (Bela Negara) institution in campus is not adequate with their military skill, but at least their competencies give a chance to attribute with an attribute as state defense pioneers in universities and colleges all around Indonesia. The fact that Student Regiment is one of Student Activity Unit and also as supporting defense component is referring that the interest for developing and empowering Student Regiment dominantly executed by Ministry of Culture and Education and Ministry of Defense. Because of military skill requirement, TNI Head Quarter (Markas Besar TNI) should be contributes in the program under Ministry of Defense supervision. The engagement of TNI in Student Regiment Development and Empowerment should be based on a clear the Rule of Engagement and legitimated as a part of TNI 's task and function as main component in preparing other defense component. The first step to do is an overall review in Student Regiment policies and in line with Law No. 23/2019, and the review should be other stakeholders, at least Ministry of Domestic affairs and Ministry of Youth and Sport because of previous joint agreement letter between them. Four Ministry Joint Agreement Letter in 2014 should be replace with more strong regulation, such as Presidential Regulation or Governmental Regulation which tied all stakeholders.

\section{CONCLUSIONS AND RECOMMENDATIONS}

Ministry of Culture and Education and Ministry of Defense are two key stakeholders in Student Regiment development and empowerment in Indonesia Defense System. Law No. 23/2019 is issued as the newest regulation which guiding Student Regiment's role in Indonesia Defense System after Indonesia democracy reform.

Overall review on Student Regiment policies is necessary to ensure that the program will be executed based on Law No. 23/2019. Other stakeholders such as: Ministry of Domestic Affairs, Indonesian Armed Forces (TNI), Ministry of Youth and Sport and local government will be involved if necessary. Updated and strong regulation from Indonesia government is required not only as guidance but also as a legal fundamental form for running the program.

\section{SOURCES OF FUNDING}

This research received no specific grant from any funding agency in the public, commercial, or not-for-profit sectors.

\section{CONFLICT OF INTEREST}

The author have declared that no competing interests exist.

\section{ACKNOWLEDGMENT}

None.

\section{REFERENCES}

[1] Freeman, R. Edward (1951), Strategic management, A Stakeholder Approach, University of Minnesota, Pitman Publishing Ins., 1020 Plain Street, Marshfield, Massachusetts, 95.

[2] Ministry of Defense of the Republic of Indonesia (2015), Indonesian Defense White Paper 2015, Ministry of Defense of the Republic of Indonesia, ISBN 978-979-8878-04-6, Medan Merdeka Barat Street, 13rd-14th, Jakarta, Indonesia, 57-112.

[3] Letjend. TNI. Waris, Prof. Dr. Armai Arief,MA, Irjend.Pol. Drs. Bambang Suparno, dkk (2013), SETENGAH ABAD RESIMEN MAHASISWA JAYAKARTA :Merambah Jalan Belantara Reformasi di Pusat Ibukota Negara, PPNI Publishing, Januari 2013, 5-6.

[4] Mohamad Hisyam Mohd. Hashim (2016), The Advantages of Reserve Officer Training Unit (ROTU)'s Activities to Future TVET Teachers, Asian Research Journal of Arts \& Social Sciences, 1(3): 1-8, 2016, Artic no. ARJASS.27125, 2. [5] Muhammad Harry Riana Nugraha (2017), Indonesian Future Strategic Defense Planning, Jurnal Pertahanan Vol. 3 No. 3, 217.

[5] Bhatara Ibnu Reza (2017), THE TOTAL PEOPLE'S DEFENSE AND SECURITY SYSTEM: PROBLEMS OF STATESPONSORED MILITIA IN INDONESIA Volume 7 Number 2, May - August 2017 INDONESIA Law Review, 174. 
[6] Leonila C. Crisostomo (2017), Benefits and Difficulties of the National Service Training Program in Rizal Technological University, IRCHE 2017 4th International Research Conference on Higher Education Volume 2018, 831.

[7] Bayu Setiawan (2017), Formation Pattern State Defense Reserve Components in Five Countries of Asean JOURNAL OF BUSINESS \& BEHAVIOURAL ENTREPRENEURSHIP, Vol. 1 No. 1, December 1, 2017, 25-26.

[8] Mohd Noor Azli Ali Khan, et al (2019)., The Significance of Reserve Officer Training Unit Student as Part of Jawatankuasa Kolej Mahasiswa at Kolej Tun Dr. Ismail on The Reserve Officer Training Unit Student's Perspective Advances in Social Science, Education and Humanities Research, volume 470, Proceedings of the International Conference on Student and Disable Student Development 2019 (ICoSD 2019), 78.

[9] Dinn Wahyudin \& Andi Suwirta (2020), Politics of Curriculum in the Educational System in Indonesia, TAWARIKH: Journal of Historical Studies, Volume 11(2), April 2020, 153. 